\title{
Bioethical Guidelines of 'Extreme Triage' Under Covid: The Question of 'Possible Lives' in Latin America
}

Abril Saldaña-Tejeda

DOl. 10.21931/RB/2020.05.04.27

\begin{abstract}
The essay briefly looks into the bioethical guide of extreme triage and resource allocation based on known comorbidities (i.e., obesity, hypertension, and diabetes). I invite to reflect upon how a focus on individual responsibility under COVID-19 occludes major structural problems while silencing the social factors behind the heath disaster that we are witnessing today. The essay argues that chronic diseases are not merely the result of genetic makeup or individual choices but are instead profoundly linked to poverty, systemic racism, structural violence, and lack of care. Debates on extreme triage guidelines and resource allocation illuminate a series of ethical shortcomings that preexisted COVID-19. Even if guidelines clearly state that criteria such as race, gender, or class will not be taken into account when deciding how to allocate limited medical resources, these categories are deeply linked to health disparities, and therefore, on people's possibilities of surviving the pandemic.
\end{abstract}

Key words: COVID-19, bioethics, extreme traige, comorbidites, health inequalities.

Assuming a shortage of medical resources to treat patients with Covid-19, many Latin American countries have discussed or established bioethical guides for limited resource allocation in the case of a public health emergency or what is known as 'extreme triage.' Under the principle of social justice, these guides propose to allocate resources to save as many lives as possible. Countries such as Chile, México, Argentina, Colombia, Brazil, and Uruguay have discussed the establishment of triage teams to administer scarce resources based on two main criteria: the possibility that a patient will improve and survive (that is, the presence vs. the absence of co-morbidities) and the time the patient will take to recover. In many countries, the additional recommended principle is to allocate resources to those who can have more years of life saved. That is, younger patients.

An emergency resource allocation strategy certainly involves abandoning the Hippocratic Oath, the idea of equality between people, and the sacredness of life. However, in a crisis like the one we are experiencing now, health professionals require direction to proceed in the event of facing limited resources in a scenario that seems inevitable. Bioethical procedures need to be discussed and agreed upon before impromptu and discretionary decisions are made by health professionals overwhelmed by the physical and emotional burden of the current crisis. Helen Ouyang ${ }^{1}$, a New York emergency department doctor, vividly describes her experience in the midst of the pandemic as hospitals get flooded by patients, dead and alive. Her experience demonstrates the need for bioethical guidance on 'extreme triage' for those at the front of the pandemic risking their own physical and emotional lives to save the lives of others. However, there is also a need to question some of the assumptions behind these triage guidelines.

Bioethical triage guidelines have sparked a heated debate across the globe 2 . Bioethicists have been accused of playing God by deciding who deserves the chance to live and who doesn't. In many countries, public opinion has forced bioethicists to rewrite and retract many of the recommendations for limited medical resource allocation. Many complaints have been directed towards the utilitarian ethics that often inform 'extreme triage' guidelines that propose the allocation of scarce medical resources with the sole idea of saving as many lives as possible. The most prominent criticisms were focused on age discrimination.

For instance, in Mexico, some went as far as comparing the bioethical triage guidelines to Nazi's atrocities against those perceived as old or ill ${ }^{3}$. In Argentina, a group of bioethicists questioned age as a factor in decision making since a young individual can suffer from more severe pathologies than an older one, and therefore be less likely to survive the virus ${ }^{4}$. In contrast to the outcry over what many perceived as age discrimination, little has been said about co-morbidities as a factor that would make someone less likely to survive. This is especially problematic as there is growing evidence to suggest that many chronic diseases are not merely the result of genetic makeup or individual choices but are instead profoundly linked to poverty, systemic racism, structural violence, and lack of care $^{5}$. Failing to look at the preexisting conditions of our health systems and the struggles of those suffering from chronic diseases before Covid-19 could easily imply that critical medical resources are denied to those for whom the state has already failed to protect. As Palmer ${ }^{6}$ suggests, when highlighting how wellness is increasingly being presented as a lifestyle choice, 'even before the pandemic, they [the chronically ill] had been used to the medical system giving up on them before they were given a chance.' Moreover, many of those that are being identified as particularly 'at risk' of Covid-19 are being denied the care they regularly receive as surgeons or hospitals find themselves overwhelmed by the Covid-19 crisis $^{7}$. Given the economic toll of the pandemic, it seems unlikely that health care systems around the world will be able to maintain [in many countries, already inefficient] pre- Covid-19 levels of care for patient groups.

As a society, we decide on the allocation of resources on a daily basis. Triage guidelines have merely illuminated a series of ethical shortcomings that preexist in the crisis. Even as guidelines state that criteria such as race, gender, or class will not be taken into account when deciding how to allocate limited medical resources, these categories are indeed involved in the configuration of health disparities, and therefore, on the likelihood of someone surviving the virus. Since 2015, Latin America has seen a severe increase in poverty rates and extreme poverty that directly affects health inequalities ${ }^{8}$. Covid-19 has 
exposed the extent of such inequalities across the Latin American region. For instance, there are disproportionate rates of infection and death among indigenous peoples. As of May 18th, there were up to 20,000 confirmed cases of Covid-19 among indigenous peoples from the Amazonia and in its 2,400 territories across eight countries ${ }^{9}$. Black Brazilians are said to be 62 percent more likely to die from the virus than whites, not only because of unequal access to health services but also because of the close correlation between race and chronic diseases such as diabetes and hypertension ${ }^{10}$. Women constitute up to 70 percent of health workers across the region; they are not only at the front of the pandemic but are also the target of attacks by those fearing contamination ${ }^{11}$.

In some cases, domestic violence is taking more women's lives than Covid-19, and women are disproportionately taking the burden of domestic and care work during lockdown ${ }^{12}$. Finally, migrants, refugees, and displaced people are also being disproportionately affected by Covid-19, not only because of stigmatization in host countries but also because of the impact of border shutdowns that have left thousands of people trapped, without basic needs for survival ${ }^{13}$. In the case of Mexico, people treated at a private hospital were said to be 60 percent less likely to die by COVID-19 than those in public health units ${ }^{14}$. Up to 71 percent of COVID-19 fatalities were among people with the educational attainment of primary school or less (i.e., incomplete primary school, no studies), and up to 46 percent were retired, unemployed or part of the informal economy ${ }^{15}$. As these numbers suggest, race, class, and other social factors are directly behind the devastating effects of COVID-19. A bioethical approach to the allocation of medical resources under Covid-19 must consider that many of the bodies marked as 'more likely to survive the virus' were previously configured by colonial histories of racism, violence, and dispossession ${ }^{16-18}$. As Barnes et al. ${ }^{19}$ suggest, 'care always has a past and how we respond to past injustices is one of the largest ethical questions we need to face.' Bioethics must engage with our regional past to address our present and future practices of care.

Covid-19 doesn't exist in isolation and requires that we consider social and structural conditions as preexisting and problematic ${ }^{20}$. Some of these conditions are embodied by individuals (i.e., age or co-morbidities), but others are found in institutional practices and policy approaches to address Covid-19. A preexisting condition could be found in the current denigration of our health systems or the so-called 'care deficit' as the effect of the international migration from Latin America. However, another preexisting condition could be the place of bioethics in the region and the low impact that research has had in policy-making ${ }^{21}$. We must confront the possible limits of bioethics to account for the political nature of the new place that science and medicine have in the world of politics to face unexpected challenges such as Covid-1922.

Bulcock ${ }^{23}$ describes the general features that distinguish Ibero-American from American bioethics. She identifies the communitarian character of the former versus the individualistic or autonomy-centered of the latter. The author looks at the central role of physicians and theologians in the development of an Ibero-American bioethics that identified itself as a social and political movement. In contrast, the establishment of American bioethics was institutionalized by academia and philosophy departments. Some Latin American theoretical approaches assert such distinction. For instance, complex, intervention, and protection bioethics are all theoretical models critical of individualistic and autonomy-centered approaches and all engage with a broader view of bioethics capable of encompassing human rights, public health, and social inequality ${ }^{24-25}$. However, confronting Covid-19 from a bioethical approach requires us to problematize the very notion of the community before and after the crisis. Following Esposito, we must rethink the basis of our political and social relations to unveil how, in the name of the 'common', we have reactivated the worst forms of structural violence ${ }^{26}$. Mestizaje, as the foundational myth found in many of the region's national histories, is one example of how in the name of a 'common' origin, indigenous, black, and Asian ancestries were to be violently and progressively erased from national identities. Mestizaje is still today the logic that works to deny the persistence of racist practices across many countries in Latin America through the idea that we have all a shared past, and we are all mixed ${ }^{27}$.

In the post-pandemic world, bioethics must go beyond procedures and ethical committees to fully understand the challenges ahead. Following Esposito ${ }^{28}$, Covid-19 presents a particular biopolitical dynamic that manifests in three particular features: the change of focus from individuals to population segments (i.e., identification and surveillance of 'at risk' and 'a risk' groups); a process where politics becomes medicalized, and medicine gets politicized, and finally, the increasing entanglement of political and biological life that allows for the transference of democratic action to states of emergency. If we aim to fully grasp the way forward, we must explore the political implications of these processes in our own contexts. For instance, in Mexico, Giovanni López, a 30-year-old bricklayer, was beaten to death by police officers for not wearing a face mask in public. As Giovanni's unlawful killing shows, police brutality must be seen as another preexisting condition that complicates the forced implementation of state measures to care for the broader population under Covid-19.

The current focus on the body (i.e., the presence of co-morbidities) seems to work as a mechanism to leave the state unaccountable for the political and social roots of health inequalities. This notion of the body as private or apolitical could also be behind the stigmatization and condescending practices that often occur when labeling whole groups of people as vulnerable ${ }^{29}$. For instance, a private amusement park in the city of Monterrey, northeast Mexico, announced that people [perceived by staff as] suffering from obesity were to be forbidden entrance for their protection from coronavirus ${ }^{30}$. The park didn't specify how its staff would be able to 'diagnose' someone as obese or if measures would be implemented to avoid discrimination. Companies are starting to refuse to hire people with chronic diseases, over 55 years of age, and other forms of 'risks' under COVID-1931. People are reported being denied entrance into casinos (gambling businesses) if they are perceived as obese for 'their own protection.' Other forms of COVID-19'S co-morbidities that are not seen as easy to diagnose through sights, such as diabetes or hypertension, are allowed to occupy these spaces freely. This leads us to ask, who or what are these businesses 'protecting'? What forms and meanings the notion of 'protection' or 'care' take in these cases? We must be attentive to the way these notions are used and how they are heavily charged with complex and, sometimes, contradictory meanings.

\section{Conclusions}

When it comes to the current state of emergency, it is also crucial to think about new and old forms of power in the region and their potential impact when managing the administration of life under Covid19. We must engage with a bioe- 
thical approach to the allocation of care not only in times of emergencies but through the everyday care responsibilities grounded in democracy. As Tronto ${ }^{32}$ suggests, 'democracy is not simply giving people a voice. It is giving people a voice in the allocation of caring responsibilities'. Following a theoretical tradition that attempts to go beyond an autonomy-centered approach to bioethics, we must engage with a democracy centered on care, one that could genuinely grasp the particular caring needs and obligations of states during and after Covid-19. As Garland-Thomson ${ }^{33}$ suggests, disability bioethics reminds us of the need to transform medical subjects into political ones. Bioethical guides for extreme triage must acknowledge that decisions to allocate limited care during a health crisis are often shaped by past injustices and by the health inequalities that result from structural violence. It is only by accounting for those silenced and complex stories embodied by patients before arriving at the emergency room that we could truly engage with an ethical practice of care.

\section{Funding}

A Wellcome Small Grant supported this publication in $\mathrm{Hu}-$ manities and Social Science. Reference: 218699/Z/19/Z

The Medical Anthropology Blog Series published a previous version of this essay at the University of Central London: https://medanthucl.com/2020/09/15/bioethical-guidelines-of-extreme-triage-under-covid-the-question-of-possible-lives-in-latin-america/

\section{Bibliographic references}

1. Ouyang H. I'm an E.R. Doctor in New York. None of Us Will Ever Be the Same. The New York Times. April 14th 2020. Available from: https://www.nytimes.com/2020/04/14/magazine/coronavirus-er-doctor-diary-new-york-city.html. [Accessed October 28th 2020].

2. Del Missier G. Overwhelmed by the virus: the issue of extreme triage. Alphonsian Academy Blog. March 27th 2020. Available from: https://www.cssr.news/2020/03/overwhelmed-by-the-virus-the-issue-of-extreme-triage/ [Accessed 28th October 2020]

3. Miranda P. UNAM se deslinda de guía que relega a ancianos con Covid-19. El Universal. April 15th 2020. Available from: https:// www.eluniversal.com.mx/nacion/expertos-critican-guia-que-prioriza-jovenes-sobre-ancianos-con-covid-19 [Accessed 28th October 2020].

4. Woites A M. Especialistas en bioética reflexionan sobre los desafíos que se afrontan ante el nuevo coronavirus Télam. 17 April 2020. Available from: https://www.telam.com.ar/notas/202004/453069-bioetica-salud-coronavirus-pandemia. html?fbclid=IwAR2aQodB5IGW20ecxcYON18sbowDJ2ur-dWIWODX2bmgUKINfUSqza3v4BA [Accessed 28th October 2020].

5. Burnett C, Carney M A, Carruth L, Chard S, Dickinson, M, Howard M. Anthropologists Respond to The Lancet EAT Commission. Revista Bionatura. 2020. 5 (1): 1023-1024. Available from: doi: 0.21931/RB/2020.05.01.2.

6. Palmer A. Wellness is a seductive lie-and it is changing how we treat illness. The Guardian. June 22nd 2020. Available from: https://www.theguardian.com/books/2020/jun/22/wellness-is-a-seductive-lie-abi-palmer-sanatorium [Accessed 28th October 2020].

7. Manderson L, Wahlberg A. Chronic Living in a Communicable World. Medical Anthropology. 2020;39(5):428-439. Available from: doi: 10.1080/01459740.2020.1761352

8. Abramo L, Cecchini S, Ullmann H. Addressing health inequalities in Latin America: the role of social protection. Ciência \& Saúde Coletiva. 2020, 25(5): 1587-1598. Available from: doi: 10.1590/1413-81232020255.32802019
9. Organización Panamericana de Salud. Directora de la OPS llama a proteger a los grupos vulnerables de los efectos de la pandemia de COVID-19. 19 May 2020. Available from: https://www.paho. org/es/noticias/19-5-2020-directora-ops-llama-proteger-grupos-vulnerables-efectos-pandemia-covid-19. [Accessed 28th October 2020].

10.Genot, L. In Brazil, Coronavirus Hits Blacks Harder Than Whites. Barron's. May 7th 2020. Available from: https://www.barrons. com/news/in-brazil-coronavirus-hits-blacks-harder-thanwhites-01588886404 [Accessed 28th October 2020].

11. United Nations Population Fund. Covid-19 a Gender Lens: protecting sexual and reproductive health and rights and promoting gender equality. March 2020 Available from: https://www.unfpa. org/sites/default/files/resource-pdf/COVID-19_A_Gender_Lens_ Guidance_Note.pdf [Accessed 28th October 2020].

12. Regnér A. Frenteal coronavirus, las mujeres somos la primera línea de defensa. The Washington Post. 7 April 2020. Available from: https://www.washingtonpost.com/es/post-opinion/2020/04/07/ frente-al-coronavirus-las-mujeres-somos-la-primera-linea-de-defensa/ [Accessed 28th October 2020].

13. Segnana J. La situación de los migrantes en América Latina en el contexto del COVID-19', PNUD América Latina y el Caribe. 19 May 2020. Available from: https://www.latinamerica.undp. org/content/rblac/es/home/blog/2020/la-situacion-de-los-migrantes-en-america-latina-en-el-contexto-d.html. [Accessed 28th October 2020].

14. Solís, P., Carreño H. 2020. 'COVID-19 Fatality and Co-morbidity Risk Factors among Confirmed Patients in Mexico'. MedRxiv. 2020: 1-8. Available from: https://doi.org/10.1101/2020.04.21.

15. Hernández Bringas H. Mortalidad por COVID-19 en México. Notas preliminares para un perfil sociodemográfico. Notas de Coyuntura del CRIM 2020 (36):1-7. Available from: http://doi.org/10.22201/ crim.001r.2020.36

16. Yates-Doerr E. The Weight of Obesity: Hunger and Global Health in Postwar Guatemala. Oakland: University of California Press; 2015.

17. Gálvez A. Eating NAFTA: Trade, Food Policies, and the Destruction of Mexico. Oakland: University of California Press; 2018.

18. Mendenhall E. Rethinking Diabetes: Entanglements with Trauma, Poverty, and HIV. Ithaca and London: Cornell University Press; 2019.

19. Barnes M, Brannelly T, Ward L, Ward N. Introduction: the critical significance of care. In: Barnes M, Brannelly $T$, Ward L, Ward N (eds.) Ethics of Care: Critical Advances in International Perspective. Bristol: Policy Press; 2015. p. 3-19.

20. Mendenhall E. Why Social Policies Make Coronavirus Worse. Available from: https://www.thinkglobalhealth.org/article/whysocial-policies-make-coronavirus-worse [Accessed 28th October 2020].

21. Garcia L F, Fernandes M S, Moreno J D, Goldim J R. Mapping Bioethics in Latin America: History, Theoretical Models, and Scientific Output. Journal of Bioethical Inquiry. 2019, 16(3):323-331. Available from: doi: 10.1007/s11673-019-09903-7.

22. Hernández Martínez C N. De Van R Potter a Michel Foucault o de la bioética a la biopolítica como estrategia de análisis en el debate en torno a las biotecnologías. In: Corona Fernández J. (coord.) Poder y subjetividad. Emplazamientos para una reflexión sobre el presente. México: Itaca/Universidad de Guanajuato; 2019. p. 95-119.

23. Bulcock J A. The Many Beginnings of Bioethics: A Comparison of American and Ibero-American Bioethics and the Possibility of a Global Bioethics. In: Pessini L, Paul de Barchifontaine C, and Lolas Stepke $F$ (eds) Ibero-American Bioethics. History and Perspectives. London and New York: Springer; 2010. p. 379-386.

24.Garcia, L. F., Fernandes, M. S., Moreno, J. D., \& Goldim, J. R. (2019). Mapping Bioethics in Latin America: History, Theoretical Models, and Scientific Output. Journal of Bioethical Inquiry, 16(3), 323-331.Goldim, JR. Revisiting the beginning of bioethics: the contribution of Fritz Jahr (1927). Perspect Biol Med. 2009, 52(3):377-380. Available from: doi: 10.1353/pbm.0.0094. 
25. Port D, Garrafa V. Bioética de intervenção: Considerações sobre a economia de Mercado [Intervention bioethics: Considerations on market economy]. Revista Bioética. 2005, 13(1): 1122-1132.

26. Bird G, Short J. Community, immunity, and the proper an introduction to the political theory of Roberto Esposito. Angelaki. 2013,18(3): 1-12. Available from: doi: 10.1080/0969725X.2013.834661.

27. Moreno Figueroa M. Distributed intensities: Whiteness, mestizaje and the logics of Mexican racism. Ethnicities. 2010, 10(3): $387-$ 401. Available from: doi: 10.1177/1468796810372305.

28. Esposito R. Biopolítica y coronavirus. Available from: https:// www.filco.es/biopolitica-y-coronavirus/ [Accessed 28th October 2020].

29. Luna F. (2019). Revisiting Vulnerability: Its Development and Impact. In Controversies in Latin American Bioethics. In: Lopez E, Rivera M (eds) Controversies in Latin American Bioethics. London and New York:Springer, 2019. p. 67-81.

30.Zuñiga F. Personas con obesidad, niños y adultos mayores no podrán entrar al parque Fundidora. 4 July 2020. Milenio. Available from: https://www.milenio.com/ciencia-y-salud/sociedad/coronavirus-personas-obesidad-entrar-parque-fundidora
31. Casasola, Tania. 17 de septiembre, 2020 'EI COVID nos trajo discriminación': Niegan empleo por tener diabetes, hipertensión y obesidad. Animal Político. Available from: https://www.animalpolitico.com/2020/09/covid-niegan-empleo-enfermos-diabetes-hipertension-obesidad-discriminacion

32. Tronto J. Democratic caring and global care responsibilities. In: Barnes M, Brannelly T, Ward L, Ward N. (eds.) Ethics of Care: Critical advances in international perspective. Bristol: Policy Press; 2015.p. 21-30.

33.Garland-Thomson R. CRISPR and Human Identity: Governing Germline Gene Editing. 30 years of the Genome Integrating and Applying ELSI Research. Columbia University. June 15th 2020. Available from: https://www.mhe.cuimc.columbia.edu/our-divisions/division-ethics/elsi-virtual-forum/elsi-virtual-forum-video-recordings [Accessed 2 November 2020].

Received: 15 August 2020

Accepted: 3 November 2020 